\title{
O NEOCONSERVADORISMO RELIGIOSO E HETERONORMATIVIDADE: A "BOLSONARIZAÇÃO" COMO PRODUÇÃO DE SENTIDO E MOBILIZAÇÃO DE AFETOS
}

\author{
Elizabeth Christina de Andrade Lima ${ }^{1}$ \\ Isabelly Cristiany Chaves Lima²
}

RESUMO: $O$ artigo analisa a construção de narrativas antes e durante a campanha eleitoral para presidente da República do Brasil, em 2018. Tendo como protagonista o agora eleito Presidente Jair Messias Bolsonaro, observamos que sua narrativa é marcada pelos discursos de medo e de ódio dirigidos a todos aqueles que, na sociedade, antagonizam com a sua maneira, e de seus apoiadores, para pensar o papel da família, da propriedade e do Estado. Consideramos que tais narrativas ajudaram a construir a sua imagem pública para conseguir a aderência de uma considerável parcela da sociedade que, doravante, orgulha-se em se identificar como de direita, conservadora, favorável à família, à moral e aos bons costumes.

PALAVRAS-CHAVE: Neoconservadorismo. Bolsonarização. Heteronormatividade. Produção de sentidos e de afetos.

\section{NEOCONSERVATORISM IN RELIGION AND HETERONORMATIVITY: "BOLSONARIZAÇÃO" AS PRODUCTION OF MEANING AND MOBILIZATION OF AFFECTS}

ABSTRACT: The article analyzes the construction of narratives before and during the Presidential campaign for the Republic of Brazil, in 2018. We note that the narrative of the

\footnotetext{
1 Universidade Federal de Campina Grande (UFCG), Campina Grande - PB - Brasil. Professora Titular de Antropologia. Universidade Federal do Ceará (UFC), Fortaleza - CE - Brasil. Doutora em Sociologia. Orcid: https://orcid.org/0000-0003-3072-3624. ecalima@terra.com.br.

2 Universidade Federal de Campina Grande (UFCG), Campina Grande - PB - Brasil. Doutoranda pelo Programa de Pós-Graduação em Ciências Sociais. Orcid: https://orcid.org/0000-0002-9787-7604. isabelly.uepb@gmail.com.
} 
now-elected Jair Messias Bolsonaro is marked by speeches of fear and hatred addressed to all those who, in society, antagonize him and his supporters to think about the role of the family, private property and the State. We believe that such narratives helped to build its public image in order to achieve the adherence of a considerable part of society, which, henceforth, prides itself on identifying itself as right-wing, conservative, in favor of the family, morals and good customs.

KEYWORDS: Neoconservatism. Bolsonarização. Heteronormativity. Production of meanings and affections.

\section{Introdução}

Parafraseando o ex-Presidente Lula "nunca antes na História do Brasil" vivemos tantas emoçóes durante um pleito eleitoral. A campanha para a Presidência da República, nas Eleiçóes de 2018, fugiu a todo e qualquer script, inimaginável acreditar que o Brasil, do ponto de vista político, e agora cultural, social e econômico, passaria por tantas transformaçóes.

Anos antes, em 2014, os brasileiros elegeram o Congresso mais conservador do período pós Ditadura Civil Militar brasileira de 1964-1985, a expansão dos evangélicos com a agenda conservadora avançou nos meios de comunicação de massa, na política partidária, no mercado musical, no mercado literário, além do vasto crescimento de igrejas pentecostais e neopentecostais; pesquisas corporativas do Ibope de 2010, 2016 e 2018 apontaram a proporçáo do conservadorismo referente às pautas do casamento entre pessoas do mesmo sexo, da legalização do aborto, da redução da maioridade penal, da prisão perpétua para crimes hediondos e da adoçáo de penas de morte, com um crescimento de $49 \%$ para $54 \%$ e, posteriormente, para $55 \% .^{3}$

A tradição escravocrata, sexista, misógina, patriarcal, racista, judaico-cristã, patrimonialista, coronelística, oligárquica, elitista, hierárquica e utilitarista igualmente são ingredientes que produzem e reproduzem o conservadorismo brasileiro. "[...] valores historicamente preservados pela tradição e pelos costumes" (BARROCO, 2015, p.624).

O candidato eleito para a Presidência da República Federativa do Brasil, Jair Messias Bolsonaro e, consequentemente a "Direita Alternativa” e a Bolsonarização (SOLANO, 2018) passam a compor uma nova gramática e uma estética, que não surgiram especificamente com Bolsonaro, mas tem nele uma

\footnotetext{
Disponível em: https://piaui.folha.uol.com.br/grafico-conservadorismo/. Acesso em: 18 ago. 2020.
} 
espécie de protótipo, em consequência, sobretudo, da coalizão composta por neoliberais, neoconservadores, agropecuaristas, ativistas religiosos autoritários, classe média profissional e elite brasileira.

Este artigo trata desse contexto de chegada ao poder de uma persona política que soube, de forma magistral, encenar um personagem que atende as demandas dessa parcela da população brasileira que estamos classificando de ultraconservadora e de extrema direita, que se ampara no discurso religioso e nos valores tradicionais da defesa da família e da propriedade como âncoras a sustentar uma "nova forma" de ver e dizer o mundo e o Brasil.

\section{1. "E conhecereis a verdade a verdade vos libertará", ou "a religião é o ópio do povo": a guerra de narrativas}

O palco é improvisado, mas o script está treinado. Ao som de uma plateia numericamente modesta, mas efusivamente participativa, em frente ao único aeroporto da cidade de Campina Grande, no interior do Estado da Paraíba, vimos Jair Messias Bolsonaro encenar a fé judaico-cristâ, no palanque da política partidária: "[...] como somos um país cristão, Deus acima de tudo" foram as suas primeiras palavras.

Continuou o roteiro: "Não tem essa história, essa historinha de Estado laico não. É Estado cristão e quem for contra que se mude”. No enredo teocrático, os personagens principais serão as maiorias: "Vamos fazer o Brasil para as maiorias. As minorias têm que se curvar às maiorias [...] as minorias se adequam ou simplesmente desaparecem ${ }^{4 \prime}$.

A religiosidade do Estado e a politização da fé são capitalizadas como retóricas que consubstanciam a construção da imagem pública de Jair Messias Bolsonaro, acrescenta-se a isso o combate às minorias "desadequadas”, "abjetas", que estão "alterando a ordem social": LGBT+, mulheres, população indígena, negros (as);

Movimento negro, feminismo ou Movimento LGBTQIA, são, para os bolsonaristas, grupos que sofrem preconceito, sim, mas estão abusando de seus direitos. Utilizam-se da vitimização, do mimimi para obter regalias do Estado e abala os cidadãos que não pertencem a essas minorias (SOLANO, 2018, p.1, grifo nosso).

\footnotetext{
4 É possível recuperar a enunciação do deputado no seguinte, conforme a publicação disponível em: https://www. diariodocentrodomundo.com.br/video-nao-tem-essa-historinha-de-estado-laico-e-estado-cristao-disse-bolsonaroem-comicio/. Acesso em: 15 ago 2020.
} 
Assim, Jair Bolsonaro capitaliza uma linguagem que encontra adesão e faz sentido para um grupo de pessoas que se sente conectado cognitiva, emotiva, performática e simbolicamente. Desse modo, passa a ser o representante de uma comunidade simbólica que se diz "oprimida" pela ditadura das minorias. Minorias essas que têm gerado desestabilização das estruturas naturais, imprevisibilidade quanto ao futuro. Assim, a falaciosa narrativa da possibilidade de extinção da humanidade, com o crescimento numéricos de gays e feministas, é anunciada e, como resposta, acarreta movimentos como orgulho hétero, que se pensam como subversivo e contra a ideologia "dominante" de esquerda.

Com mais de cinco milhóes de seguidores no Facebook, o fato é que Bolsonaro representa uma direita que se comunica com os jovens, uma direita que alguns jovens identificam como rebelde, como contraponto ao sistema, como uma proposta diferente [...]. O uso das redes sociais, a utilização de vídeos curtos e apelativos, o meme como ferramenta de comunicação, a figura heroica juvenil do "mito Bolsonaro", falas irrelevantes até ridículas, falas fortes, destrutivas, contra todos, são aspectos que atraem os jovens. (SOLANO, 2018, p.7, grifo nosso).

Com as qualificaçóes de autêntico, divertido, antissistema, determinado, corajoso, transparente, íntegro etc., Jair Messias Bolsonaro se utiliza da espetacularização da fé e, consequentemente, da pauta religiosa da família, da moral e dos bons costumes, da disciplina, da autoridade para se mostrar como um político com uma missão quase sagrada: mudar o Brasil ${ }^{6}$.

Assim, presencia-se um neoconservadorismo que apresenta novas formas de controle social, em várias esferas como na educação com o Movimento Escola Sem Partido e as discussóes da Ideologia de Gênero, que se dizem como uma iniciativa contra ideológica, com o intuito de extirpar a contaminação político-ideológica das escolas brasileiras, aliando-se a uma proposta de educação e sociedade tradicional, sem pluralidade.

Alencar (2015) ressalta que a novidade desse neo, da palavra conservadorismo, refere-se à intelectualização do discurso, sobretudo para os grupos evangélicos, que visam amalgamar as necessidades dos indivíduos modernos com as

\footnotetext{
5 Ideologia que é narrada por esses grupos como a detentora dos meios de comunicação tradicionais (Organizações Globo, Folha de São Paulo), digitais (Facebook), aos sistemas de ensino (universidades e escolas públicas) e partidos políticos (PSDB, MDB, PP etc., e todos os partidos políticos de esquerda).

6 "Muda, Brasil! Muda de verdade! Bolsonaro com amor e com coragem" foi trecho do jingle de campanha política. Disponível em: https://conexaopolitica.com.br/eleicoes/jair-bolsonaro-lanca-jingle-para-campanha-a-presidenciamuda-brasil-muda-de-verdade/. Acesso em: 15 ago 2020.
} 
demandas seculares. Tem-se, portanto, um cenário de novos conservadorismos de matriz religiosa (D’AVILA, 2015), no qual a moral desempenha uma figura de destaque na propulsão da Bolsonarização.

É importante destacar o que se compreende por Bolsonarização. Mapeando os "[...] principais elementos de identificação dos eleitores com o discurso do Bolsonaro", Solano (2018, p.1) faz uma análise empírica e teórica das condiçôes que propiciam o surgimento desse fenômeno, no Brasil, que é um processo complexo e de múltiplas variáveis.

Para tanto, Solano (2018) elenca alguns fatores conjunturais e estruturais. Para a ela, a instabilidade democrática nacional e a ameaça aos direitos mais fundamentais impulsionaram a penetração de uma nova direita, que se apresenta de forma cool, pop, com a identificação com a rebeldia e se propóe contra o sistema (que é visto como de esquerda), escamoteando o discurso de ódio em formas de memes e vídeos divertidos.

Todavia,

[...] o fato é que o fenômeno Bolsonaro é muito maior que a viabilidade de sua candidatura. A penetração e capilaridade de suas ideias, a retórica e a mensagem nos diversos segmentos da população e o crescimento exponencial de sua intenção de voto devem nos fazer pensar que não estamos tratando da ameaça individual de Jair Messias Bolsonaro e, sim, da ameaça de um processo de "bolsonarização", ou seja, a popularização de uma política antidemocrática, autoritária de extrema direita, que continuará para além do indivíduo em si (SOLANO, 2018, p. 10).

Assim, compreende-se, a partir da formulação apresentada, a nomeação de Bolsonarização não como um processo de fulanização de uma dinâmica social, nem, muito menos, um fenômeno surgido com o personagem político em cena. A nomenclatura, usada por Solano (2018), trata-se de uma escolha metodológica e didática, uma tipologia que pretende sistematizar uma realidade concreta vivenciada no Brasil contemporâneo, o fato de o presidente eleito ter sabido capitalizar e se utilizar de um processo que foi se construindo.

Solano (2018) ainda frisa que, como um processo, a Bolsonarização tem como persona Jair Bolsonaro, ao mesmo tempo em que ultrapassa o indivíduo e reverbera em mudanças nas paisagens sociais, culturais, políticas. E, por ser processo, pode-se dizer que ainda está em movimento, podendo progredir, transformar-se ou se exaurir. Todavia, não é algo espontâneo, automático ou que deva ser ignorado ou subestimado. A propagação faz parte de múltiplas variáveis de 
determinaçôes estruturais e conjunturais, uma dinâmica conjuntural geopolítica tanto macro quanto micro estrutural.

Pode-se destacar macroestruturalmente: o efeito Donald Trump nos Estados Unidos da América, aliado ao processo de uma direita alternativa internacional, como destacados por Solano (2018), e o fortalecimento da extrema direita nas recentes eleições europeias, frisado por Löwy. ${ }^{7}$. Em dez teses sobre a ascensão da extrema direita na Europa, Löwy (2014) aponta algumas tendências observadas há alguns anos na Europa, entre elas, a aderência eleitoral à extrema direita, um fenômeno sem precedente desde os anos de 1930. Isto é: essa corrente obtinha, em muitos países, entre 10 e $20 \%$, mas atualmente tem aumentado cerca de $15 \%$ a taxa de adesão de votos. Como é muito diversa, essa direita se apresenta tanto em partidos abertamente neonazistas (o Aurora Dourada grego) quanto naqueles que fazem o jogo político institucional (a União Democrática de Centro suíça). Todavia, ainda segundo Lowy (2014), o que eles têm em comum é o nacionalismo excessivo, a xenofobia, o racismo, o ódio contra imigrantes, a islamofobia, o anticomunismo e, em muitos casos, o antissemitismo, a homofobia, a misoginia, o autoritarismo, o desprezo pela democracia e a eurofobia. Outro fator que merece destaque é a contaminação da extrema direita nas ideias da direita dita clássica e até em partes da esquerda ${ }^{8}$ social-liberal.

Microestruturalmente: no Brasil, a ascensão do Congresso mais conservador pós Ditadura, em 2014; as manifestaçóes de rua, em 2013, que segundo Wink (2018) tem como ponto fulcral a saída da direita do "armário" e a apreensão de que defender os posicionamentos de forma não velada (assim, como o politicamente incorreto) eram uma fórmula para o sucesso; a indústria da crise, em 2016, como narrativa reiterada pela grande mídia; a espetacularização da corrupção, com a Operação Lava Jato; a ruptura democrática acarretando o impeachment da ex-Presidenta Dilma Rousseff (PT) e, em consequência, o antipetismo, o antissistema, a antipolítica; a prisão do ex-Presidente Luiz Inácio Lula da Silva (PT). Outro fator relevante é a cultura de ordem. Barroco (2015, p. 626) destaca que essa cultura contou, a partir dos anos 1990, com a fundamental colaboração de programas de TV sensacionalistas, como os apresentados por Ratinho e Datena, que "incentivando medidas de força em nome da ordem passaram a expor, diariamente, crimes e delitos [...] numa campanha escancarada

\footnotetext{
É importante pontuar que não se quer dizer que esses são os únicos contextos macroestruturais, nem se objetiva apontar se são os mais importantes, se são causas ou consequências.

8 A esquerda também necessita de uma reflexão mais apurada e detalhada, porém, não é objeto deste trabalho.
} 
de defesa da militarização da vida social, do armamento, do rebaixamento da maioridade penal e da pena de morte no Brasil"'.

Um movimento de múltiplas variáveis, em que não se pode considerá-lo de modo isolado, estanque, mas como uma teia, unida, entrelaçada e se entrelaçando, cheia de furos e vazamentos, como os contextos sociais específicos de produção, entre eles os descontentamentos, as frustraçóes, que encontraram terreno favorável à reprodução, sendo capitalizados por Bolsonaro e que ainda estão em vias de construção, em cujo transpassar do tempo, permitir-se-á dimensionar os efeitos concretos, as transformaçóes morfológicas e axiológicas.

Para Barroco (2015), as formas dominantes de apologia ao anti-humanismo, ao individualismo, ao pessimismo, à dissimulação das contradiçóes sociais, como características do neoconservadorismo, servem para combater o Estado Social e os direitos sociais (Welfare State), reprimindo as formas de contestação à ordem social e aos costumes tradicionais. Além disso, novas formas de sociabilidades, advindas principalmente da inserção das igrejas evangélicas no Brasil, sobretudo nas periferias, são grandes colaboradoras da difusão dos valores capitalistas, da meritocracia e da individualização do esforço (SOLANO, 2018).

Singer (2012) salienta que também houve uma virada à direita da igreja católica, que nas décadas de 1960 e 1970 teve uma grande relevância para a esquerda brasileira e, por isso, arrastava camadas extensas da sociedade. Singer (2012) lembra que a onda neoliberal começou a influenciar a igreja católica nos anos de 1980 e, lentamente, foi sendo introduzida no Brasil. E “[...] Isso é muito importante para entender a presença da hegemonia cultural da esquerda e depois sua quebra. A esse fator se soma um segundo, que é a avalanche pentecostal e neopentecostal no Brasil" (SINGER, 2012).

Num ambiente, sendo paulatinamente construído, de sensação de violência, de corrupção generalizada, da iminente chegada do anticristo, do perigo comunista e socialista, os principais projetos do ainda Deputado Federal Bolsonaro ganham apoio e aderência. A exemplo do ódio destilado às ONGs, aos índios e aos quilombolas:

Se eu chegar lá (na presidência), não vai ter dinheiro pra ONG. Esses inúteis vão ter que trabalhar. Se eu chegar lá, no que depender de mim, todo cidadão vai ter uma arma de fogo dentro da casa. Não vai ter um centímetro demarcado pra reserva indígena ou para quilombola (EU SOU..., 2018, $)^{10}$.

\footnotetext{
9 Reconhece-se que há outras variáveis tão importantes quanto as elencadas, mas, tal abordagem, não é objeto de reflexão nessa produção textual.

${ }^{10}$ Disponível em: https://theintercept.com/2018/10/20/quem-e-jair-bolsonaro-17/. Acesso em: 14 ago. 2020.
} 
É com esse enredo unido aos anseios de uma sociedade, caracterizado por fortes traços conservadores, que o discurso de Bolsonaro, nos mais diferentes ambientes, ganha notoriedade, apoio e crença de que ele traria para o Brasil um novo tempo de prosperidade e de respeito à família, à propriedade e ao Estado.

\section{2. "As minorias que se curvem às maiorias" são as palavras de ordem}

O discurso da moral cristã (contra os direitos reprodutivos das mulheres e em favor de uma assistência psicológica a LGBT+, por exemplo), que vimos acima, aliado aos princípios cruciais do neoliberalismo na política e na economia (Estado Mínimo e Livre Mercado) vem com o escopo de que é preciso salvar, a todo custo, a família (ALENCAR, 2015), reparar e consertar o país que, até então, estava entregue a socialistas. $\mathrm{O}$, agora, Presidente do Brasil, no primeiro ano de seu governo e em discurso proferido na Assembleia da ONU, no dia 24 de setembro de 2019, assim se manifestou logo no início de sua fala:

Apresento aos senhores um novo Brasil, que ressurge depois de estar à beira do socialismo. Um Brasil que está sendo reconstruído a partir dos anseios e dos ideais de seu povo. (...) Meu país esteve muito próximo do socialismo, o que nos colocou numa situação de corrupção generalizada, grave recessão econômica, altas taxas de criminalidade e de ataques ininterruptos aos valores familiares e religiosos que formam nossas tradiçóes ${ }^{11}$.

Apontado como um mal que precisa ser extirpado provocado pela onda socialista, Bolsonaro, e seu governo, apresentam-se como uma espécie de salvadores da pátria, cuja função precípua será a de impor uma nova ordem social, desta feita, na defesa e, principalmente, proteção inconteste aos valores da família cristã, heteronormativa, branca, disciplinada, elitista. A grande responsável pelo desmantelamento do Brasil é, segundo o novo Presidente, a ideologia de esquerda, patrocinada e propalada pelo partido que governou o Brasil antes de ele assumir o poder, o Partido dos Trabalhadores - PT e seus presidentes: Luiz Inácio Lula da Silva, de 2002 a 2009 e Dilma Rousseff, de janeiro de 2010 a agosto de 2016.

Em outro ponto de seu discurso, proferido na ONU, é possível ler claramente tal assertiva:

\footnotetext{
11 Disponível em: https://exame.com/brasil/leia-na-integra-o-discurso-de-bolsonaro-na-assembleia-da-onu/. Acesso em: 14 ago. 2020.
} 
Durante as últimas décadas, nos deixamos seduzir, sem perceber, por sistemas ideológicos de pensamento que não buscavam a verdade, mas o poder absoluto. A ideologia se instalou no terreno da cultura, da educação e da mídia, dominando os meios de comunicação, universidades e escolas. A ideologia invadiu nossos lares para investir contra a célula mater de qualquer sociedade saudável, a família. Tentam ainda destruir a inocência de nossas crianças, pervertendo até mesmo sua identidade mais básica e elementar, a biológica. O politicamente correto passou a dominar o debate público para expulsar a racionalidade e substituí-la pela manipulação, pela repetição de clichês e pelas palavras de ordem. A ideologia invadiu a própria alma humana para dela expulsar Deus e a dignidade com que Ele nos revestiu. (... $)^{12}$.

A “ideologia de esquerda” a qual o Presidente Bolsonaro faz menção se baseia em um discurso inventado por sua equipe de marketing político para seduzir e conquistar os votos e apoio de uma parcela da sociedade, principalmente os evangélicos pentecostais e neopentecostais, além de uma parcela da Igreja Católica de ala mais conservadora, amedrontada pela possibilidade de certas pautas como a liberalizaçáo do aborto, o casamento entre pessoas do mesmo sexo, a convivência com o diferente na sociedade como um todo: travestis, transexuais, lésbicas, gays se tornar natural. De outro lado, visa, igualmente, a conquistar a parte mais conservadora e preconceituosa da sociedade, uma elite ressentida e incomodada com a ascensão econômica, cultural, intelectual e social das classes populares, que por séculos serviram e se subjugaram a essa elite, sem questionar o seu "lugar social", nos termos de Bourdieu (2010).

Com a chegada de Bolsonaro à presidência do Brasil, ser de direita, identificar-se como conservador, religioso, a favor da família heteronormativa, da moral $e$ dos bons costumes, da meritocracia, da disciplina da caserna, do Brasil verde e amarelo, entre outros, passam a ser valores não só exaltados como manifestados publicamente.

Magali Cunha (2016, p.176) chama a atenção especialmente para a virada da primeira década do século XXI, em que se pode perceber uma intensa visibilidade de lideranças defensoras de "[...] ideais e posturas explicitamente conservadoras e que se apresentam como modernas pertencentes aos novos tempos, em que a religião tem como aliados o mercado e as tecnologias". Ou, como frisou Barroco, "Ser de direita virou moda" (BARROCO, 2015, p. 632).

12 Idem. 
Ademais, nesse contexto, ser de esquerda passa a ser algo repugnante; pode-se observar um conservadorismo que surge como reação às transformaçóes socioculturais experimentadas nos anos recentes, sobretudo a partir de 2002, quando se abriram políticas públicas afirmativas direcionadas para os direitos humanos e de gênero (CUNHA, 2016).

Toitio (2016) faz um balanço sobre a luta pela diversidade sexual e de gênero, sob o neoliberalismo brasileiro. Para tanto, é investigada a participação da ABGLT (Associação Brasileira de Gays, Lésbicas, Bissexuais, Travestis, Transexuais e Intersexos) durante os Governos de Fernando Henrique Cardoso, Luiz Inácio Lula da Silva e Dilma Vana Rousseff, respectivamente.

De forma resumida, pode-se dizer que durante o governo de Fernando Henrique Cardoso, a relação Estado e Sociedade Civil da ABGLT ainda estava baseada na esfera da prestação de serviços. Durante os mandatos de Lula, a mediação abandona o viés fundamentado na prestação de serviços para se basear na construção de participação política.

Nesse cenário político de abertura, começa-se a discussão sobre a confluência de elementos e concepçóes do projeto político da ABGLT, em relação ao governo, e como as pautas do movimento poderiam ser assimiladas dentro do projeto neodesenvolvimentista;

Nos anos de 2000, houve um alargamento substantivo dos espaços e frentes de atuação do movimento LGBT. Grupos e coletivos independentes, organizações não governamentais, setores formados no interior de partidos e sindicatos, coletivos do movimento estudantil ou de juventude, associaçôes, fóruns, redes etc. tornaram-se presentes por todo o país e cada vez mais visíveis. Nesse período, ainda, o Brasil se tornou o país que mais realizava paradas de orgulho, além de passar a abrigar a maior do mundo (em São Paulo), ao mesmo tempo em que passou a investir em políticas sociais voltadas para a população LGBT (TOITIO, 2016, p. 17).

Certo avanço nos direitos foi visto como ameaça e o fator representativo de Dilma Rousseff ser a primeira mulher eleita para ocupar o maior cargo do Executivo, no Brasil, não foram suficientes para assegurar e acentuar ainda mais as pautas políticas das minorias, já que seu mandato foi marcado pelo "[...] fortalecimento do neoconservadorismo evangélico no Congresso Nacional e a construção de uma agenda em oposição ao movimento LGBT e ao feminista" (TOITIO, 2016, p. 50) e, desde o início da campanha dos presidenciáveis, as referências religiosas foram uma marca proeminente dos embates propositivos. 
Desse modo, assim como a Carta ao povo brasileiro foi um anúncio de como seria a política econômica do governo Lula, a Carta ao povo de Deus foi o primeiro indício de como o governo Dilma trataria as políticas e direitos sexuais: estes só seriam disputados pelo governo na medida em que não afetassem sua política de alianças, cuja composição incluía partidos conservadores. (TOITIO, 2016, p. 183).

Singer (2012) lembra que o lulismo (incluindo o período de governabilidade de Lula e Dilma) propôs mudanças, mas de modo comedido e sem radicalização, sem um confronto extremado com o capital e, com isso, conservou a manutenção da ordem. Nesse sentido, Singer (2012) classifica o lulismo como um fenômeno híbrido, que, portanto, captura o conservadorismo. Assim, "[...] uma análise mais simplista e dicotômica não consegue dar conta da complexidade da situação que estamos vivendo" (SINGER, 2012).

A propositura "irmão vota em irmão ${ }^{13 "}$ também começou, aos poucos, a povoar o imaginário evangélico, contrapondo-se, conforme Romancini (2018), a um passado progressista, em que o Estado laico era uma das pautas do protestantismo, no início do século XX. A política que era associada como "coisa do mundo" (CUNHA, 2016), secular, passou a conviver com outros ideais: é necessário colocar meu semelhante ideológico como representante nas grandes tomadas de decisóes, na defesa da família e da moral cristã, contra as plataformas dos movimentos de minorias, especialmente dos movimentos feministas e LGBT $+{ }^{14}$. Tudo isso em uma afronta direta à laicidade do Estado.

Os evangélicos não são mais "os crentes" ou os grupos fechados de outrora. A separação social, "do mundo", deixa de ser um valor evangélico da tradição fundamentalista-puritana: são hoje um grupo que desenvolve a cultura "da vida normal" combinada com a religião com presença nas mídias, moda própria, artistas e celebridades, inserção no mundo do mercado e do entretenimento (CUNHA, 2016, p. 158).

\footnotetext{
${ }^{13}$ Cunha (2016) alerta para que a presença da religião cristã, de vertente evangélica, não seja vista como uma ameaça, mas que seja percebido como uma possibilidade própria da democracia. Além do mais, é necessário alargar as compreensões reducionistas, que tratam quaisquer grupo como homogêneo, ademais, é preciso questionar as naturalizações e privilégios religiosos, a laicidade do Estado, uma vez que "[...] a fé católica romana interfere na dinâmica social, política e cultural do país, a começar com a existência de feriados nacionais relacionados aos santos e às festas católicas, passando pelos crucifixos em destaque nas paredes das repartições públicas", "[...] o Acordo Brasil-Vaticano, de 2009, que concede isenção tributária a instituições católicas, privilegia a Igreja Católica no ensino religioso nas escolas, e garante cooperação para preservar e valorizar os bens culturais católico-romanos" (CUNHA, 2016, p. 159). O ponto crucial está na possibilidade de abrir o diálogo com essas novas vozes.

${ }^{14}$ Em 2011, a atuação da Frente Parlamentar Evangélica (FPE) trouxe para agenda a luta contra os movimentos feministas e de homossexuais.
} 
Esse bloco articulado de autorrepresentação partidária, visualizado pela bancada da Bíblia e pela Frente Parlamentar Evangélica, valendo-se de aliança com os católicos, o que era historicamente impensável no campo religioso, utiliza-se de argumentos pretensamente sagrados para legitimar preconceitos, dando viabilidade ao fundamentalismo, em um país que atinge de forma direta e variada negros, mulheres, jovens da periferia, sujeitos "fora" da ordem, da lei, dos costumes, do pensamento dominante (BARROCO, 2015). Um país perpassado pela desigualdade social, racial, sexual e de gênero.

Tudo isso em uma visão equivocada (mas, proposital) de que as expressóes da questão social e a crise do capitalismo estão relacionadas (e são consequências) da desagregação moral, da desestruturação da família, da desarrumação dos valores tradicionais, sendo, portanto, necessário tratar essas expressões como caso de polícia, na violência física e simbólica.

Soares (2017) também salienta que essa onda conservadora é um prenúncio aos direitos sociais e humanos que estão em desestruturação no Brasil. Sendo, por conseguinte, importante considerar que há uma vertente interpretativa que defende o conservadorismo brasileiro como um processo que se reatualizou em um neoconservadorismo com modos inéditos de violação de direitos humanos, formas variadas de violência contra trabalhadores, destruição de direitos historicamente conquistados, apelo à ordem, fundamentalismo, xenofobias e discriminaçôes (BARROCO, 2015).

Dantas (2016) acrescenta:

Durante a votação do processo de impeachment, ocorrido em Brasília no dia 24 de abril deste ano [2016], ficou claro que a política parlamentar no Brasil é perpassada pela moralização das expressōes da questão social. Dos/ as 367 deputados/as que votaram a favor do processo de Impeachment, todos/as usaram referência em nome da família e da moral do país. Foram 511 votos ao total. 137 contrários ao impedimento, 7 abstenções e 2 ausências. (DANTAS, 2016, p. 42, grifo nosso).

Percebe-se que as justificativas dos deputados favoráveis ao processo de impeachment da ex-Presidenta Dilma Rousseff são motivadas por questóes morais e sociais de uma direita dita cristá, que reivindica uma cidadania religiosa do Deus judaico-cristáo acima de tudo e de todos, com uma leitura anacrônica da Bíblia para defender uma ordem moral universal, que se coloca como representante única do lugar universal de fala, de religião, de sexualidade, “[...] que em nome da família abomina tudo aquilo que direta ou indiretamente fere a tradição, o discurso religioso" (SCHEEFFER, 2014, p. 13). O foco na moral 
sexual, com rígidas compreensôes sobre certo e errado, ocultando determinaçóes sociais, culturais, históricas, econômicas.

Nesse cenário conservador religioso, a busca por uma cultura cristã se torna plano narrativo que embasa o enredo de uma direita alternativa brasileira e possibilita o fortalecimento de um neoconservadorismo ${ }^{15}$, que cresceu a partir de micro e pequenos partidos políticos.

No pleito de 2018, pode-se afirmar que houve uma alteração de paradigma na base ideológica da direita brasileira. É necessário, portanto, a construção de um novo mapa conceitual, abrangendo a diversidade de temas, atentando para uma nova realidade social (SCHEEFFER, 2014), expressa com a Bolsonarização, que parece ter impulsionado o reposicionamento das forças sociais e a redefiniçáo do termo direita, que foi usado náo apenas restrito ao uso conceitual da Ciência Política, mas revisitado e convocado no pleito de 2018 como atalhos informacionais.

Mesmo a partir do exposto, é importante afirmar que houve uma variedade de espectros de direitas e de conservadorismos na adesão a Bolsonaro. Não são todos com atitudes fascistas, nem neoconservadores fundamentalistas. Solano (2018) explica que o voto em políticos populistas autoritários e de extrema direita, como Donald Trump, Jair Bolsonaro ou Marine Le Pen, que oferecem respostas simplórias e, muitas vezes, enganosas para realidades complexas é consequência de uma vulnerabilidade existencial da pós-democracia, que leva os eleitores a um desespero ontológico, a uma sensação de medo constante, a um saudosismo conservador.

Há comunidades (no plural) de pertencimento variadas. De forma didática e ainda muito incipiente pela falta de mais materialidades, e reconhecendo que toda tentativa de nomeação e de generalização apresenta limitaçóes, a nova direita - uma expressão cunhada em contraposição à direita tradicional, herdeira política de partidos que apoiaram a Ditadura -, geralmente, é filiada ao pensamento liberal-conservador, de matriz britânica, que era representada principalmente pelo $\mathrm{PSDB}^{16}$.

\footnotetext{
${ }^{15}$ Os termos conservadorismo, neoconservadorismo, direita, nova direita, muitas vezes são usados indiscriminadamente, negligenciando a historicidade, os fatores concretos. Assim como há um uso variado por parte da população, também há por grande parte dos autores, pois os termos servem como categorias da ciência política e como atalho informacional. Quando há citações bibliográficas, tem-se preferido manter o uso que o autor selecionado abordar. Entretanto, prefere-se a opção direita alternativa em consonância com a bolsonarização, uma vez que a nova direita foi uma expressão cunhada em contraposição a direita tradicional que seria herdeira política de partidos que apoiaram a ditadura. Como a nova direita nega o passado da ditadura, a opção pelo termo, em conformidade com o pensamento de Bolsonaro, não é apropriada. Tentou-se fazer um enquadramento, mas se reconhece que a realidade é fluida.

16 João Dória, eleito governador de São Paulo, no pleito de 2018, radicalizou o discurso, afastando-se do conservadorismo liberal para se aproximar da estratégia de Bolsonarização, a fim de angariar votos.
} 
A diferença substancial da direita alternativa brasileira é a popularização do extremismo de direita, a partir da filiação ao neoconservadorismo e aprofundada pela Bolsonarização, que reatualiza a linguagem e a estética, popularizando-as. Antes o Brasil só tinha, no máximo, socialdemocracia e todos os partidos, declarada ou não declaradamente, eram de esquerda, com presumidos ideais socialistas/comunistas de destruição da propriedade privada (por isso, a criminalização dos movimentos MTST, MST), da família (por isso, a necessidade do Estatuto da Família ${ }^{17}$, da Escola Sem Partido, da Cura Gay ${ }^{18}$ ), da religião (por isso, o Estado é cristão, nas palavras de Bolsonaro). Uma estratégia narrativa em que se estabelece uma leitura linear da realidade, de fácil apreensão por sua divisão maniqueísta entre bons e maus.

Georg Wink (2018) alega que no Brasil, diferentemente de outros países, a nova direita (que neste trabalho chama-se de direita alternativa brasileira) envolve um maior número de agentes políticos e sociais como, por exemplo, as principais igrejas pentecostais e neopentecostais; os neointegralistas, que em 2004 fizeram o seu primeiro congresso depois de anos; parte das forças repressivas; os monarquistas com seu poder de influência sobre a mídia social; empresários; os ideólogos como Olavo de Carvalho; o apoio de uma infraestrutura internacional consolidada com muito poder político, midiático e financeiro, como o Millenium, o Mises e o Liberal, que estão por trás de movimentos como o MBL, os think tanks; além do contexto de vulnerabilidade brasileira como a desestabilização do consenso democrático (o impeachment) e, consequentemente, recessão e desemprego.

Como a direita alternativa brasileira é composta de partidos, majoritariamente, sem densidade política significativa como o PRTB, PR, PSC, PSL, Patriotas, quer-se passar a ideia de que são anti-mainstream, anti-estabelichmet, outsiders, lançando proposituras de pastores, monarquista, agentes de segurança pública, jornalista, general das Forças Armadas, capitão reformado do Exército etc. É necessário ressaltar que esses partidos nem sempre se apresentaram ideologicamente como neoconservadores e aliados a uma direita extremista. Caldeira Neto (2016) lembra que a "viragem" à direita do PRTB de Levy Fidelix e do

\footnotetext{
${ }^{17}$ Pretende limitar o conceito de família ao modelo patriarcal, afetando, com isso, a legalização da união estável entre pessoas do mesmo sexo, a adoção de filhos por casais homoparentais etc.

18 "O fato que deu maior visibilidade ao conflito entre fundamentalismo e movimento LGBT, exacerbando-o, foi a aprovação de um projeto de lei que permite o tratamento psicológico para a homossexualidade (e, também, a bissexualidade e a transexualidade), numa votação presidida por Feliciano. O projeto, que foi apelidado de cura gay, era de autoria de João de Campos e suspendia trechos de uma resolução de 1999 do Conselho Federal de Psicologia, que proibiam os profissionais de participarem de serviços que propusessem o tratamento e cura das homossexualidades e de emitirem opinião pública que classifique homossexuais como portadores de desordem psíquica" (TOITIO, 2016, p. 194.).
} 
vice presidente do Brasil eleito no pleito de 2018, General Hamilton Mourão, tem como marco a eleição de 2014, cuja retórica do candidato à presidência, Levy, foi pautada pelo neoconservadorismo e o moralismo, em defesa da família heteronormativa.

À época, sob o lema "Endireita Brasil", ainda com uma pequena repercussão e visibilidade, encampando uma profunda resistência às políticas afirmativas dos LGBT+; pleiteou a narrativa da Ditadura de 1964 como revolução e baseou-se em teorias conspiratórias, de referencial olavete, como a de que o programa Mais Médicos era composto de agentes revolucionários. Desse modo, o PRTB passou de caricato para ocupar um lugar na alocação do campo político, em uma estratégia que surtiu efeito: 58.000 votos em 2010, $446.878 \mathrm{em}$ 2014 (CALDEIRA NETO, 2016) e 57.797 .847 em 2018, com a coalizão com o PSL ${ }^{19}$.

Enfim, a construção narrativa de que os partidos tradicionais são corruptos, profissionalizantes, burocráticos, cartelizados, mercenários e, principalmente, articulados com a ideia de ameaça de esquerda (comunismo) que, portanto, era o momento de mudar, apresentou um impacto na cartografia do Congresso eleito em 2018. O PSL, uma sigla pequena, mudou a correlação de forças na Câmara Federal e se tornou a segunda maior representação partidária, com 52 deputados e 04 senadores, antes do pleito de 2018 não tinha nenhum senador e havia elegido, em 2014, apenas 01 deputado. O PSDB e o MDB, siglas influentes nas decisóes das pautas do Congresso, encolheram 46\% e 48\%, respectivamente ${ }^{20}$. Já o PT, apesar de todos os ataques da direita e de seu principal líder estar condenado por corrupção, continua a ser o maior partido progressista do País e parece que não perdeu a conexão ideológica, emocional e psicológica, resistindo com o segundo lugar no pleito de 2018, para o cargo da presidência da República.

Vale frisar que, apesar de toda essa classificação, não se pode omitir o fato de que essa polaridade direita versus esquerda e sua relação com o conservadorismo e o capitalismo não são compreendidas por toda a sociedade brasileira, seja pela pouca politização e grau de instrução (pode-se citar as Ciências Sociais como uma disciplina que só recentemente foi adicionada no currículo da Educação Básica, especificamente no Ensino Médio), seja pela falta de tempo para se informar, de interesse pela temática, por várias

\footnotetext{
${ }_{19}$ Disponível em: https://g1.globo.com/jornal-nacional/noticia/2018/10/29/tse-conclui-votacao-jair-bolsonaro-tevepouco-mais-de-55-dos-votos.ghtml. Acesso em: 14 ago 2020.

${ }^{20}$ Disponível em: https://www.cartacapital.com.br/politica/a-eleicao-que-transformou-a-politica-brasileira?utm campaign=newsletter_rd_-_30102018\&utm_medium=email\&utm_source=RD+Station. Acesso em: 14 ago 2020. Na reportagem ainda é salientado que o PSL se tornará, em 2019, uma das siglas mais ricas, avançando, sobretudo, sobre o MDB e o PSDB. Vai contar com a maior fatia do fundo partidário, além do segundo maior tempo de TV.
} 
motivações etc. Sendo assim, há uma parcela do eleitorado que é personalista, ou seja, impulsiona-se mais por causas concretas do que por referências ditas pretensamente ideológicas e partidárias.

Entretanto, defende-se a tese de que há um ponto de inflexão que une boa parte da comunidade simbólica desses espectros da direita: a pauta moral. Assim, a disposição em manter as estruturas, especificamente contra o kit gay, é uma das causas que compóe a construção da imagem cognitiva, afetiva, simbólica e performática de Jair Bolsonaro e, consequentemente, dos bolsonaristas.

Normalmente, o eleitor se utiliza de um ponto de inflexão com o qual o político é identificado. O caçador de marajás, o plano real, o programa Bolsa Família, por exemplo, povoam o imaginário popular remetendo, intuitivamente, a Fernando Collor de Mello, Fernando Henrique Cardoso, a Luiz Inácio Lula da Silva.

Jair Bolsonaro, por meio de "[...] uma política demagógica que manipula medos, emoçóes e afetos" (SOLANO, 2018, p.6) foi se projetando com a pauta moralista de defesa do modelo de família tradicional, contra o kit gay e a sexualização das criancinhas. Um imaginário que foi se construindo, estabelecendo significação, compartilhando repertório e encontrando adesão de uma parcela do eleitorado brasileiro.

Em janeiro de 2016, em uma publicação em seu site oficial ${ }^{21}$, o então deputado trouxe à luz novamente o programa Escola sem Homofobia, denominado por parte do grupo da direita como kit gay. O programa foi uma iniciativa do Ministério da Educação de distribuir, nas escolas públicas de todo o país, um material informativo sobre dois temas transversais propostos pelo Parâmetro Curricular Nacional: gênero e sexualidade, mas que devido à pressão conservadora foi vetado em 2011, ainda no mandato eletivo da então presidenta Dilma Rousseff.

Esse evento trouxe grande visibilidade para Jair Bolsonaro. A grande mídia optou por seu lado na arena discursiva e preferiu propagar o nome kit gay à Escola sem Homofobia ${ }^{22}$. Assim, uma iniciativa contra o preconceito foi reconfigurada como um ataque à família, à honra, à inocência das crianças, à tradição, aos bons costumes que a esquerda, juntamente com o PT, estava destruindo.

\footnotetext{
${ }^{21}$ Disponível em: https://medium.com/democratize-m\%C3\%ADdia/revista-do-grupo-abril-refuta-jair-bolsonaroem-5-minutos-30e9fe30b015. Acesso em: 14 ago 2020.

22 Disponível em: http://g1.globo.com/politica/noticia/2011/02/bolsonaro-critica-kit-gay-e-diz-querer-mudaralguma-coisa-na-camara.html; https:/veja.abril.com.br/blog/reinaldo/bolsonaro-o-kit-gay-do-mec-e-as-loucurascoletivas/. Acesso em: 14 ago 2020.
} 
Com isso, o ódio e o medo foram fermentando-se e Jair Bolsonaro passou a ser aquele que encampou a luta coletiva contra todos aqueles que estavam subvertendo os valores morais cristalizados;

O discurso de ódio está dirigido a estigmatizar, escolher e marcar o inimigo, manter ou alterar um estado de coisas, baseando-se numa segregaçáo. Para isso entoa uma fala articulada, sedutora para um determinado grupo, que articula meios de opressão. Os que não se enquadram no modelo dominante de "[...] sujeito social nada abstrato: masculino, europeu, cristão, heterossexual, burguês e proprietário” (RIOS, 2008, p.82) são os potenciais inimigos. (CIOCCARI; EZEQUEL; MOTTINHA, 2019, p.92).

Dessa forma, a moral passou a guiar a agenda política e, por não se curvar ao mimimi das minorias, entendido como a motivação que desfibra, degenera e fragiliza as pessoas, Bolsonaro foi ovacionado como o opressor, aquele que encara a ditadura do politicamente correto, consubstanciando a regularidade temática de boa parte de seus eleitores: gênero, sexualidade e, em consequência, religiáo. Assim, o político mobilizou uma paleta de conservadorismos, dos que pretendem conservar a ordem e a estrutura social sem que, para isso, precisem eliminar o outro (sobretudo, LGBT+ e feministas), principalmente representados pelos liberais-conservadores; aos que a pauta econômica é secundária e pode ser terceirizada para um Posto Ipiranga ${ }^{23}$, já que a moralidade está acima de tudo, inclusive dos direitos humanos universais e dos direitos e garantias fundamentais, protagonizados pela direita alternativa brasileira e pelos neoconservadores.

Iasi (2015) destaca:

Não basta a oposição a um governo, um debate sobre alternativas de sociedade. Isto tudo é racional demais. É preciso colar algo mais atávico, afetivo, que mobilize paixóes irracionais. Daí a funcionalidade dos estigmas, e entre eles do anticomunismo, ainda que o alvo da raiva náo seja, nem de longe, algo parecido com uma alternativa comunista. Desta maneira eu posso atacar, pedir o impedimento, xingar, desejar matar e acusar sem entender o porquê. Simplesmente porque é comunista (ou judeu, ou negro, ou homossexual, etc....) (IASI, 2015).

\footnotetext{
${ }^{23}$ Posto Ipiranga é uma metáfora, aludindo uma campanha publicitária de um posto que tem tudo que o cliente precisa, usada por Jair Bolsonaro como bordão, fazendo referência a Paulo Guedes, que é conselheiro econômico do governo Bolsonaro e indicado como Ministro.
} 
"O inimigo torna-se a retórica que justifica todas as violências e o medo torna-se o argumento central da política" (SOLANO, 2018, p. 9). Assim, em uma visão moralista e binária de simplificação da realidade social, um sentimento profundamente humano, o medo, foi explorado como ferramenta política que produziu um inimigo em comum: o kit gay e, consequentemente, a sociabilidade homoafetiva, como mobilizadores das paixóes irracionais. Colou como atávico e afetivo. Assim, o medo se tornou o argumento central, que polarizou o debate e depois se apresentou como a esperança: Bolsonaro. Como se pode perceber no discurso proferido na Câmara, pelo então deputado, em 2010:

[...] Esses gays e lésbicas querem que nós entubemos, como exemplo de comportamento, a sua promiscuidade. Isso é uma coisa extremamente séria. O Presidente da Câmara dos Deputados tem que tomar providências no tocante a esse assunto. Nós não podemos submeter-nos ao escárnio da sociedade. [...] Essa história de homofobia é uma história de cobertura para aliciar a garotada, especialmente os garotos que eles acham que têm tendências homossexuais. [...] Pelo amor de Deus, meus colegas que estão nos gabinetes! Pelo amor de Deus! Daqui a pouco vem aqui um cidadão dizer que estou mentindo. [...] Não me agrada falar em homossexual. Eu realmente assumo o que disse na TV Câmara: se um garoto tem desvio de conduta logo jovem, ele deve ser redirecionado para o caminho certo, nem que seja com umas palmadas. Acusam-me de ser violento, mas não sou promíscuo, não sou canalha com as famílias brasileiras! (DISCURSOS..., 2010).

O ethos de capitão autoritário ecoa no discurso de quem se propóe a governar uma nação plural, miscigenada, diversa. Tentando se colocar como representante das famílias brasileiras e, com isso, oferecendo aspectos de vontade supostamente coletiva, Bolsonaro apresenta manifestaçôes claramente homofóbicas, em um país que assassina sistematicamente LGBT+.

Sem saber diferenciar comportamento, gênero, sexo biológico, sexualidade, patologia ou usando as nomenclaturas de anormais, pervertidos, desviantes como dispositivo de poder que traça uma linha entre os incluídos e excluídos do reconhecimento da dignidade e da proteção dos direitos, Bolsonaro requer a incorporação da heteronormatividade como um conhecimento adquirido e naturalizado na prática social, sem colocar o status quo em suspeição, sem questionar o rol de pretensa regularidade. E o que náo esteja normatizado, seja tido como doença, que, por isso, precisa de cura, de controle, de disciplinamento. 
Apesar do processo de despatologização e descriminalização que a politização da identidade produziu, com a revolução de gênero, de sexualidade, é notório, em pleno século XXI, o discurso eivado de preconceito, de patologização, mas “[...] como o conservadorismo cria uma comunidade simbólica, deixa de ser antiquado e passa a ser de relevância vital para aqueles que se sentem membros dessas comunidades" (CUNHA, 2015, p. 10), principalmente quando se trata de uma sociedade que construiu historicamente a imagem de LGBT+ como uma ameaça ao status quo, "[...] o homossexual passou a ser visto como uma verdadeira 'espécie' desviada e passível, portanto, de controle médico-legal” (MISKOLCI, 2007).

Miskolci (2007) adverte que os temores de degeneração sexual ("inversão sexual”) camuflavam o medo de transformação profunda em instituiçôes como a família e, em consequência, a reprodução biológica, a divisão tradicional de poder entre homem e a mulher na família e na sociedade, a manutenção dos valores e da moralidade que compóe a compreensão da ordem e visão de mundo.

$\mathrm{Na}$ enunciação do então deputado, é percebida como determinadas formas de sociabilidade representam perigo, desdobrando-se em mecanismos de resistência e controle das transformaçôes da sociedade, a partir da mobilização de pânicos morais que são caracterizados pelo modo com o qual a mídia, a opinião pública e os agentes de controle social reagem a determinados rompimentos de padróes normativos. Assim, refere-se a um temor coletivo que impulsiona uma reação social a um fenômeno considerado como perigoso, seja uma ameaça real ou um temor de que posiçóes, valores, ideologias sejam alterados. E é moral porque se teme uma suposta ameaça à ordem social ou o que se idealizou dela, como instituiçóes naturalizadas. Portanto, o pânico moral é inteiramente caracterizado quando a preocupaçáo e as reaçóes coletivas são desproporcionais ao perigo real (MISKOLCI, 2007).

Pode-se afirmar que o objeto do pânico moral pode ser algo novo ou algo que já existia, mas por motivos variados vai ganhando notoriedade. “[...] algumas vezes o pânico passa e é esquecido, exceto no folclore e na memória coletiva. Outras vezes ele tem repercussões mais sérias e duradouras e pode produzir mudanças tais como aquelas em política legal e social” (MISKOLCI, 2007). É importante salientar que a homoafetividade não é uma prática social hodierna, mas o grau de aceitação e tolerância da diversidade está em constante reavaliaçáo (MISKOLCI, 2007), com avanços e recuos.

Como se cria um estigma, uma intolerância, um preconceito, há uma violência que se expressa como pânico moral marcado pelo temor de mudança da sociedade, de modificar as fronteiras morais sociais, o que mobiliza a aver- 
são, a irracionalidade. Com isso, a concepção de Bolsonaro de que algo deve ser feito, isto é: "Vamos fazer o Brasil para as maiorias. As minorias têm que se curvar às maiorias [...] as minorias se adequam ou simplesmente desaparecem ${ }^{24 \text { " }}$ vai da adequação aos padrôes normativos e às práticas sexuais, como o controle social na regulação do comportamento, na normalização do prazer, no controle dos afetos, destituindo-os de subjetividades, de visibilidade (esconder ou viver clandestinamente os desejos); ao desaparecimento (sanatórios, presídios, campos de concentração).

Destarte, “[...] Pela família e a inocência das crianças em sala de aula que o PT nunca teve, contra o comunismo! Pela nossa liberdade! Contra o Foro de São Paulo! pela memória do coronel Carlos Alberto Brilhante Ustra, o pavor de Dilma Rousseff [...], o meu voto é sim" (BOLSONARO..., 2019) Bolsonaro, em votação para o prosseguimento do processo de impeachment de Dilma Rousseff na Câmara dos Deputados, banaliza o ódio, em favor de um saudosismo dos tempos da lei, da ordem, da heteronormatividade, do culto à masculinidade, em nome da célula nuclear da religião judaico-cristã: a família (tradicional, logo uniforme). Com isso, mostra a relação intrínseca entre o pânico moral e a ideologia neoconservadora, por seu alto teor reacionário, fundamentalista.

Para Bourdieu (2010), o poder religioso é um poder simbólico, que produz consenso sobre signos e sentidos. A cidadania religiosa neoconservadora produz um imaginário de regras e dogmas que proíbem divergências: feminismos, LGBT + são as vozes dissonantes (o neomarxismo gayzista-feminista ${ }^{25}$ ), que provocam anomia social, sentimentos de ressentimento.

Além disso, o discurso religioso, ao qual Bolsonaro se filia, da interpretação unívoca da criação homem e mulher é usado para legitimar e divinizar a violência simbólica, a fim de conter as atuaçóes heréticas e evitar novas erupçôes. A rede de relação de poder, no qual a religiâo se assenta, organiza e póe em circulação um saber como consenso, usado de forma discreta para atender determinados fins.

A proposta é uma relação de poder organizado, hierarquizado, piramidalizado, que promove relaçóes desiguais, assimétricas, por meio da operação de tecnologias políticas no corpo social, reforçando contextos assimétricos sócio e

\footnotetext{
${ }^{24}$ É possível recuperar a enunciação dos deputado no seguinte, conforme a publicação https://www. diariodocentrodomundo.com.br/video-nao-tem-essa-historinha-de-estado-laico-e-estado-cristao-disse-bolsonaroem-comicio/. Acesso em: 15 nov. 2018.

${ }^{25}$ Expressão de Olavo de Carvalho. Disponível em: https://www.youtube.com/watch?v=4b3StHWY1ms\& feature=em-uploademail. Acesso em: 14 ago 2020.
} 
historicamente constituídos e que pulsam no funcionamento diário, de macro a micro práticas.

Percebe-se, assim, a partir da fala do entáo deputado, que ele se coloca em um campo social de posição estruturada, em que a luta da minoria por espaço ou para transformar uma realidade social de preconceito, de opressão, de violência física e simbólica, vivida no Brasil, é enfatizada como espaço em que as relaçôes devem ser pela manutenção da desigualdade, pela fuga do diálogo, até em lugares de construção do saber, como a escola. Com isso, ratifica seu insuficiente conhecimento sobre as relaçôes social e historicamente construídas. Isto é: enfatiza os consensos fabricados historicamente, em que há um comportamento normal em contraponto a um comportamento "ao contrário", invertido, não aceito.

Assim, a quebra da ordem que, segundo o discurso conservador, causa desequilíbrio, gera violência, pede resposta. Uma resposta que restabeleça o equilíbrio social, que garanta que a realidade não sofra alteração. E a disciplina dos corpos é vista como aquela que pode cumprir com esse objetivo, principalmente na contenção dos corpos maleáveis e moldáveis. $\mathrm{O}$ ato moralista é apresentado como necessário para reeducar, corrigir, curar esses infratores da ordem. Tudo para um bem maior: uma sociedade padronizada.

\section{Considerações finais}

A compreensão de como se pensa a sociedade e a si mesmo, de como as tradiçôes são construídas, de como as crenças são instituídas são objeto das Ciências Sociais. Uma atividade cuja busca pretende entender a realidade, afastar-se das simplificaçóes, do imediatismo.

É fato que certas dinâmicas sociais são difíceis de serem operacionalizadas. São necessários tempo, reflexão, acuidade, rigor, sistematização. Assim, compreender os conservadorismos brasileiros da contemporaneidade à medida que as narrativas vão sendo produzidas, vividas e experienciadas é atividade complexa, especialmente quando as nomenclaturas se alastram, povoando das conversas do cotidiano aos espaços acadêmicos.

Por circularem de forma relativamente ampla e popularizada, tem-se a impressão de que são termos autoexplicativos, simplórios, atemporais. Todavia, o olhar mais atento registra que se está diante de um fenômeno complexo, principalmente devido às transformaçóes societárias. Tem-se, desse modo, uma problemática de caráter teórico, empírico e aplicado. 
Portanto, é importante empreender a revisitação dos mapas conceituais, a fim de verificar se os conceitos ainda possuem pertinência e, consequentemente, se há aplicabilidade na realidade concreta.

Sendo assim, depois do percurso deste artigo, compreende-se que se está, atualmente, diante de uma paleta de conservadorismos. Com isso, defendemos a ideia de que o conservadorismo é plural, o que significa que se levam em consideraçôes variáveis múltiplas. Além disso, na reflexão sobre as configurações dos conservadorismos brasileiros contemporâneos, entende-se que há relaçôes intrínsecas com a formação social e cultural da sociedade brasileira, apresentando-se nos pontos de regularidades sem perder de foco os pontos de fugas.

Nesse início do século XXI, sobretudo a partir da década atual (20102019), os termos direita e conservador foram mobilizados bastante como atalhos informacionais, especialmente na eleição de Jair Bolsonaro. Compreendeu-se também que o conservadorismo e a direita não são instrumentos instaurados com Bolsonaro, como seus apoiadores reivindicaram.

Todavia, não se pode negar que o personagem político em pauta capitalizou o fenômeno na construção de sua performance e, por isso, que se considera o termo Bolsonarização como uma tipologia operacional na compreensão de uma dinâmica social que atrela direita alternativa brasileira e neoconservadorismo.

Jair Messias Bolsonaro parece representar os interesses de parte de uma sociedade ressentida e inconformada por ver seus espaços de atuação pública, cultural, social e econômica serem povoados por grupos historicamente subalternos como gays, lésbicas, travestis, transexuais em ascensão e visibilidade, de tal sorte que aciona o neoconservadorismo em forma de ressentimento, ódio, preconceito, para alguns claramente perceptível, para outros de modo camuflado.

Portanto, a homoafetividade e toda e qualquer publicização sobre ela deve ser proibida, extinta, expurgada, como se imprimir-lhe visibilidade causasse a total e completa desestabilização do social, da moral e dos costumes vigentes. Inviabilizá-los ou tornar o aparecimento altamente regulado é visto como solução, já que remodelar o campo da visibilidade social parece ser inaceitável.

Dessa forma, política é linguagem, logo é signo, é símbolo, é performatividade. Jair Bolsonaro tem construído a sua retórica a partir da obediência a uma gramática fixa, rígida, neoconservadora, na qual a diversidade encontra espaços de cerceamento, o diálogo é silenciado e as transformaçôes parecem não fazer sentido.

Nesse cenário rígido e inflexível desenhado, a igualdade e a justiça social têm dificuldade para contracenar. Quer-se, portanto, um tecido social que não seja sujo de imprevisibilidade, irregularidade. A retórica do kit gay, por exemplo, 
foi um dos pontos de inflexão que a direita alternativa brasileira, por meio de um processo de Bolsonarização e do neoconservadorismo, utilizou-se para mobilizar afetos, fabricar o medo, o pânico moral.

Jair Bolsonaro capitalizou uma linguagem que encontrou adesão na sociedade e, portanto, fez sentido para um grupo de pessoas que se sente conectado cognitiva, emotiva, performática e simbolicamente. A busca por uma cultura da ordem social, nesses cenários de conservadorismos religiosos, como um ideal que precisa renascer, e que foi tônica da construção da imagem pública política de Bolsonaro, com o chamativo de Muda, Brasil, deve ser investigada.

Há, também, um combate ao conhecimento científico, por ser considerado de esquerda, assim, explora-se o senso comum, a projeção das pós-verdades e a fabricação de fakes news. E esse conhecimento alternativo e revisionista tende a ser propalado, pois as redes sociais são os meios de comunicação e de informação de bolhas que se retroalimentam, que produzem modos de sociabilidades específicos, comunidades de pertencimento, que se unem, pois a mídia (rádios, jornais impressos e televisivos) é tida, por esses grupos, como de esquerda e conivente com um projeto conspiratório de marxismo cultural.

Marxismo cultural, esse, aliado ao politicamente correto, que tem sido lido como perigo, já que tem posto em risco as estruturas naturais e sagradas, por isso o combate ferrenho a questôes identitárias, ao vitimismo e ao mimimi, que têm dividido a sociedade (branco versus negros, homem versus mulher, héteros versus homo) com diferenciaçóes que não primam por liberdade; além de alterarem o cenário do que é certo e errado, do que é aceitável e aberração, do que é livre expressão e censura.

Assim, os mitos precisam serem recompostos. O degradado precisa ser neutralizado. Tudo para a unidade da sociedade. Eis os discursos dominantes neoconservadores vislumbrando um novo velho tempo. Tempo de regresso, de ordem, de uniformidade, de estagnação. E essa guerra já dizimou (e dizima) muitas etnias, gêneros, classes brasileiras.

Pelos bons costumes, pelo status quo, contra o kit gay e a mobilidade social, o neoconservadorismo, mobilizando o medo, aprofunda as desigualdades sociais, de gênero, de sexualidade, em nome de uma cultura pretensamente cristá. Materialidades de quem compóe o capital político assentado nas relaçôes de opressão, sobretudo, em relação às expressóes de gênero e às práticas sexuais, o que estimula o ódio, fomenta o preconceito e fabrica o medo, pânicos morais.

A retórica do neoconservadorismo bolsonarista ativa paixóes, mobiliza irracionalidades. Usando o nome de Deus, o Estado é cristão, os LGBT+ e as feministas devem se adequar ou desaparecerão. Diferentemente do anunciado, 
os direitos dos LGBT+, das mulheres não estão garantidos. Não há uma ditadura neomarxista gayzista-feminista em um país no qual o número de assassinatos a LGBT + e a mulheres é assustador. A pauta antiopressão, que denuncia comportamentos e estruturas opressoras, deve ser uma reivindicação constante, sobretudo, quando o neoconservadorismo reivindica a supressão, daquele que não é natural, como uma necessidade, alegando que uns precisam padecer para que outros desfrutem da ordem e do progresso.

\section{REFERÊNCIAS}

ALENCAR, G. P. Neoconservadorismo religioso em grupos protestantes. In: SIMPÓSIO NACIONAL DA ABHR, 14., Juiz de Fora. Anais [...], Juiz de Fora: ABHR, 2015.

BARROCO, M. L. S. Não passarão! Ofensiva neoconservadorismo e Serviço Social. Serviço Social, São Paulo, n. 124, p. 623-636, out./dez. 2015.

BOLSONARO exalta Ustra na votação do impeachment em 2016. Estadáo, São Paulo, 08 ago. 2019. 1 vídeo (48 seg.). Disponível em: https:/www.youtube.com/ watch?v=xiAZn7bUC8A. Acesso em: 20 jan. 2020.

BOURDIEU, P. O Poder Simbólico. 13. ed. Tradução de Fernando Tomaz. Rio de Janeiro: Bertrand Brasil, 2010.

CALDEIRA NETO, O. Frente nacionalista, neofascismo e "Novas direitas" no Brasil. Revista Faces de Clio, Juiz de Fora, v. 2, n. 4, jul./dez. 2016.

CIOCCARI, D.; EZEQUIEL, V.; MOTTINHA, R. A eleição de Jair Bolsonaro: a construção do medo e ódio na campanha eleitoral de 2018. Revista Debates, Porto Alegre, v.13, n.3, p.89-105, set./dez. 2019.

CUNHA, M. do N. Religião e Política: ressonâncias do neoconservadorismo evangélico nas mídias brasileiras. Perseu: Revista do Centro Sérgio Buarque de Holanda, São Paulo, ano 7, n. 11, 2016.

CUNHA, L. A retórica conservadora no Brasil contemporâneo e a produção de identidades políticas. In: CONGRESSO BRASILEIRO DE SOCIOLOGIA, 17., Porto Alegre, RS. Anais [...], Porto Alegre, 2015. Disponível em: https:/www. researchgate.net/publication/281272779_A_retorica_conservadora_no_Brasil_ contemporaneo_e_a_producao_de_identidades_politicas. Acesso em: 24 ago. 2020.

DANTAS, M. M. M. Neoconservadorismo e as implicaçóes e desafios à luta feminista. 68f. 2016. Monografia (Graduação em Serviço Social) - Universidade Federal do Rio Grande do Norte, Natal, 2016. 
D’AVILA, L. Como o diabo foge da cruz: ensaística neoconservadora e dispensa religiosa. IPOTESI, Juiz de Fora, v.19, n. 2, p. 53-68, jul./dez. 2015.

DISCURSOS e notas taquigráficas. Brasília, DF: Câmara dos Deputados, 30 nov. 2010. Disponível em: http://bit.ly/3a24IGp. Acesso em: 23 jan. 2020.

EU SOU Jair Bolsonaro. The Intercept Brasil, [on-line], 20 out. 2018. Disponível em: https://theintercept.com/2018/10/20/quem-e-jair-bolsonaro-17/. Acesso em: 23 jan. 2020.

IASI, M. L. De onde vem o conservadorismo? Blog da Boitempo [on-line], 15 de abril, 2015. Disponível: https://blogdaboitempo.com.br/2015/04/15/de-onde-vemo-conservadorismo/ Acesso em: 29 ago. 2020.

LÖWY, M. Dez teses sobre a ascensáo da extrema direita europeia: $O$ novo fascismo espreita o Velho Continente. São Leopoldo: Instituto Humanitas Unisinos, jun. 2014. Disponível em: http://www.ihu.unisinos.br/170-noticias/noticias2014/532447-dez-teses-sobre-a-ascensao-da-extrema-direita-europeia-o-novofascismo-espreita-o-velho-continente Acesso em: 29 ago. 2020.

MISKOLCI, R. Pânicos morais e controle social: reflexôes sobre o casamento gay. Cadernos Pagu, Campinas, n.28, p.101-128, jan./jun. 2007. Disponível em: https:// www.scielo.br/scielo.php?script=sci_arttext\&pid=S0104-83332007000100006\&lng= pt\&tlng=pt. Acesso em: 9 ago. 2020.

ROMANCINI, R. Do "Kit Gay" ao "Monitor da Doutrinação": a reaçáo conservadora no Brasil. Contracampo, Niterói, v. 37, n. 2, 2018.

SCHEEFFER, F. Esquerda direita: velhos e novos temas. In: ENCONTRO ANUAL DA ANPOCS, 38, Caxambu, MG. Anais [...], Caxambu, MG, 2014. Disponível em: https://www.anpocs.com/index.php/papers-38-encontro/gt-1/gt27-1/9084-esquerdae-direita-velhos-e-novos-temas/file. Acesso em: 24 ago. 2020.

SINGER, A. Novas expressóes do conservadorismo brasileiro. Entrevista por Luis Brasilino. Le Monde Diplomatique Brasil [on-line], Brasília, v. 6, n. 63, 2012. Disponível em: https://diplomatique.org.br/novas-expressoes-do-conservadorismobrasileiro/ Acesso em: 24 ago 2020.

SOARES, J. M. M S. A onda conservadora: ensaios sobre os atuais tempos sombrios no Brasil. Revista em pauta, Rio de Janeiro, v.15, n. 39, p.271-275, 2017.

SOLANO, E. Crise da Democracia e extremismos de direita. São Paulo: Friedrich Ebert Stiftung Brasil, 2018. (Análise, 42). 
O neoconservadorismo religioso e heteronormatividade:

a "bolsonarização" como produção de sentido e mobilização de afetos

TOITIO, R. D. Cores e contradiçóes: a luta pela diversidade sexual e de gênero sob o neoliberalismo brasileiro. 330f. 2016. Tese (Doutorado em Ciências Sociais) Instituto de Filosofia e Ciências Humanas, Universidade Estadual de Campinas, Campinas, SP, 2016.

WINK, G. Bolsonaro é a caricatura do extremista de direita. Deutsche Welle [on-line]. Disponível em: https://www.dw.com/pt-br/bolsonaro-\%C3\%A9-a-caricatura-do-extre mista-de-direita/a-45651684 Acesso em: 15 dez. 2018.

Recebido em 01 de fevereiro de 2020.

Aprovado em 06 de julho de 2020. 